\title{
COMPLEX AEROSOL EXPERIMENT IN WESTERN SIBERIA (APRIL - OCTOBER 2013)
}

G.G. Matvienko, B.D. Belan, M.V. Panchenko, O.A. Romanovskii ${ }^{{ }^{*}}$, S.M. Sakerin, D.M. Kabanov, S.A. Turchinovich, Yu.S. Turchinovich, T.A. Eremina, V.S. Kozlov, S.A. Terpugova, V.V. Pol'kin, E.P. Yausheva, D.G. Chernov, T.B. Zuravleva, T.V. Bedareva, S.L. Odintsov, V.D. Burlakov, M.Yu. Arshinov, G.A. Ivlev, D.E. Savkin, A.V. Fofonov, V.A. Gladkikh, A.P. Kamardin, Yu.S. Balin, G.P. Kokhanenko, I.E. Penner, S.V. Samoilova, P.N. Antokhin, V.G. Arshinova, D.K. Davydov, A.V. Kozlov, D.A. Pestunov, T.M. Rasskazchikova, D.V. Simonenkov, T.K. Sklyadneva, G.N. Tolmachev, S.B. Belan, V.P. Shmargunov

\section{V.E. Zuev Institute of Atmospheric Optics SB RAS, 1 Academician Zuev sq., 634021, Tomsk, Russia, E-mail: roa@iao.ru}

\begin{abstract}
The primary project objective was to accomplish the Complex Aerosol Experiment, during which the aerosol properties should be measured in the near-ground layer and free atmosphere. Three measurement cycles were performed during the project implementation: in spring period (April), when the maximum of aerosol generation is observed; in summer (July), when atmospheric boundary layer height and mixing layer height are maximal; and in late summer - early autumn (October), when the secondary particle nucleation period is recorded. Numerical calculations were compared with measurements of fluxes of downward solar radiation. It was shown that the relative differences between model and experimental values of fluxes of direct and total radiation, on the average, do not exceed $1 \%$ and $3 \%$ respectively.
\end{abstract}

\section{INTRODUCTION}

The climate change observed for already more than one decade is recognized by the whole global community. Despite the common recognition of this problem, there is no consensus on the role of human activity in the global climate change. Thus, the studies of Antarctic ice cores have shown that for the last 650000 years there were several periods of global warming accompanied by an increase in the concentration of major greenhouse gases. It was found that the increase of temperature in the Antarctic region started several centuries before the increase of the $\mathrm{CO}_{2}$ concentration. The permanent development and improvement of climatic models requires the increasingly greater amount of data of field measurements conducted in different regions of the world. The territory of Siberia occupying about $10 \%$ of the world's land is practically not covered by the modern observation network. Taking into account the fact that every of the applied methods for investigation of aerosol characteristics is informative only in a certain wavelength range, only the combined analysis of all available experimental data can provide the correct reconstruction of the complete optical pattern of aerosol in a particular region. The objective of this study was to conduct simultaneous measurements of microphysical, chemical, and optical properties of aerosol particles in the atmospheric surface layer and in the free atmosphere with the unique set of groundbased, airborne, and spaceborne instruments in order to draw a complete pattern of the composition and state of the atmosphere over the territory of Western Siberia.

\section{MEASUREMENT SYSTEM}

The developed measurement system provides laser sensing of the aerosol content, sunphotometric measurements of the aerosol optical depth, acoustic sounding of the boundary layer, measurement of the gas composition, measurement of meteorological parameters of air. The composition and purpose of individual elements of the measurement system are summarized in Table 1.

Remote laser sensing of aerosol of the troposphere was carried out with the stationary LOZA lidar at three laser wavelengths of 355, 532, and $1064 \mathrm{~nm}$. The lidar system detects not only echo signals of elastic backscattering, but also signals of Raman scattering in night time. The multifrequency lidar provides reconstruction of high-quality information about the vertical distribution of optical and microphysical properties of aerosol. 
Table 1. Composition and purpose of individual elements of the measurement system

\begin{tabular}{|c|c|c|}
\hline Element & Purpose & URL \\
\hline Siberian Lidar Station & $\begin{array}{l}\text { High-altitude sensing of the } \\
\text { atmosphere }\end{array}$ & $\mid \frac{\frac{h t t p: / / \text { www.iao.ru/ }}{\text { en/resources/equip }}}{\mid \underline{\text { sls/s/ }}}$ \\
\hline LOZA Lidar & $\begin{array}{c}\text { For determination of aerosol } \\
\text { profile at a distance of } 1- \\
10 \mathrm{~km}\end{array}$ & \begin{tabular}{|l|} 
http://www.iao.ru/ \\
en/resources/equip \\
lidars/loza/ \\
\end{tabular} \\
\hline $\begin{array}{c}\text { Ty-134 Optik flying } \\
\text { laboratory }\end{array}$ & $\begin{array}{c}\text { Measurement of } \\
\text { meteorological parameters, } \\
\text { gas and aerosol composition } \\
\text { of air, optical characteristics }\end{array}$ & $\frac{\mid \frac{h t p p: / / \text { www.iao.rt }}{\text { en/resources/equi }}}{\text { /plane/ }}$ \\
\hline TOR s & $\begin{array}{l}\text { Monitoring of meteorological } \\
\text { parameters, gas and aerosol } \\
\text { composition of air, and solar } \\
\text { radiation in the surface layer }\end{array}$ & $\begin{array}{l}\text { http://lop.iao.ru/e } \\
\text { g/index.php/abou } \\
\text { tor-station/aero-t }\end{array}$ \\
\hline $\begin{array}{l}\text { Basic Experimental } \\
\text { Complex }\end{array}$ & $\begin{array}{l}\text { Monitoring of meteorological } \\
\text { parameters, gas and aerosol } \\
\text { composition of air, and solar } \\
\text { radiation in the surface layer }\end{array}$ & $\begin{array}{l}\text { http://lop.iao.ru/e } \\
\mathrm{g} / \text { index.php/abou } \\
\text { bec/aerosols }\end{array}$ \\
\hline $\begin{array}{c}\text { Fonovaya } \\
\text { (Background) Station }\end{array}$ & $\begin{array}{l}\text { Monitoring of meteorological } \\
\text { parameters, gas and aerosol } \\
\text { composition of air, and solar } \\
\text { radiation in the surface layer }\end{array}$ & $\begin{array}{l}\text { http://lop.iao.ru/e } \\
\text { g/index.php/abou } \\
\text { fonovyi/aerosols- }\end{array}$ \\
\hline $\begin{array}{r}\text { DigiCora } 3 \\
\text { radiosounc } \\
\text { atmos }\end{array}$ & $\begin{array}{c}\text { For determir } \\
\text { distribution o } \\
\text { parameters }\end{array}$ & \begin{tabular}{|c} 
http://www.vaisala.rn \\
Vaisala\%20Docume \\
nts/Brochures\%20an \\
$\%$ \%20Datasheets/RS92 \\
$\begin{array}{c}\text { SGP-Datasheet- } \\
\text { B210358RU-E- } \\
\text { LoRes.pdf }\end{array}$ \\
\end{tabular} \\
\hline SP-9 & $\begin{array}{l}\text { Measurement of aerosol } \\
\text { optical thickness and water } \\
\text { column of the atmosphere }\end{array}$ & \begin{tabular}{|l|} 
http://link.springer \\
com/article/10.11 \\
$34 / \mathrm{S} 10248560130$ \\
$4012 \mathrm{X}$ \\
\end{tabular} \\
\hline Aeros & $\begin{array}{c}\text { Measurements of } \\
\text { characteristics of surface } \\
\text { aerosol } \\
\end{array}$ & $\begin{array}{c}\text { http://aerosoll.iao } \\
\text { ru/index.php?lang } \\
\text { eeng } \\
\end{array}$ \\
\hline $\begin{array}{c}2.4 \text { XLB Direct } \\
\text { Broadcast Reception } \\
\text { System }\end{array}$ & $\begin{array}{l}\text { Reception of satellite } \\
\text { from AVHRR, MODIS } \\
\text { other optoelectronic de }\end{array}$ & \begin{tabular}{|l|} 
http://www.orbital \\
systems.com/anten \\
na- \\
products/systems/ \\
eosdb-systems/ \\
\end{tabular} \\
\hline $\begin{array}{l}\text { Meteo-2 Ultrasonic } \\
\text { Meteostation }\end{array}$ & $\begin{array}{c}\text { Measurement of mean values } \\
\text { and characteristics of wind } \\
\text { turbulence and air } \\
\text { temperature }\end{array}$ & $\frac{\frac{\text { http://www.iao.ru }}{\text { en/resources/equi }}}{\frac{/ \text { dev/meteo2/ }}{\underline{4}}}$ \\
\hline na & $\begin{array}{l}\text { Measurement of vertical } \\
\text { profiles of wind vector } \\
\text { components in the } \\
\text { atmospheric boundary layer }\end{array}$ & $\frac{\mid \begin{array}{l}\text { http://www.iao.ru/ } \\
\text { en/resources/equip }\end{array}}{\text { /dev/sodar/ }}$ \\
\hline
\end{tabular}

We will first consider the systems used for measurements in the surface air and then describe the devices for determination of the integral content of sought parameters and their vertical distributions. Continuous measurements of the concentrations of minor atmospheric constituents were carried out at three stations for monitoring of the atmospheric composition owned by IAO SB RAS: Fonovaya Observatory, TOR station, and Basic Experimental Complex (BEC) [1]. To study the vertical distribution of the climatically significant components of the troposphere, we used the analytical equipment installed aboard the
Tu-134 Optik flying laboratory [2]. The temperature-wind sounding was carried out with the Vaisala DigiCORA ${ }^{\circledR}$ MW31 radiosonde. Aerosol measurements at the stationary IAO Aerosol Station are conducted with the use of the methods for investigation of aerosol properties. The aureole photometer measures the directed scattering coefficient and is used for estimation of the mass content of coarse particles in the size spectrum. For monitoring of temperature, humidity, ozone, aerosol, and clouds the data of MODIS multichannel spectroradiometer installed on Terra and Aqua platforms were mostly used. The developed measurement system allows us to reconstruct the whole set of microphysical, chemical, and optical characteristics of aerosol from measured data.

\section{MEASURING SITES}

Permanent measurements of the concentration of minor constituents were carried out at the three stations for monitoring of the atmospheric composition belonging to IAO SB RAS (Fig. 1): Fonovaya Observatory, TOR Station, and Basic Experimental Complex.

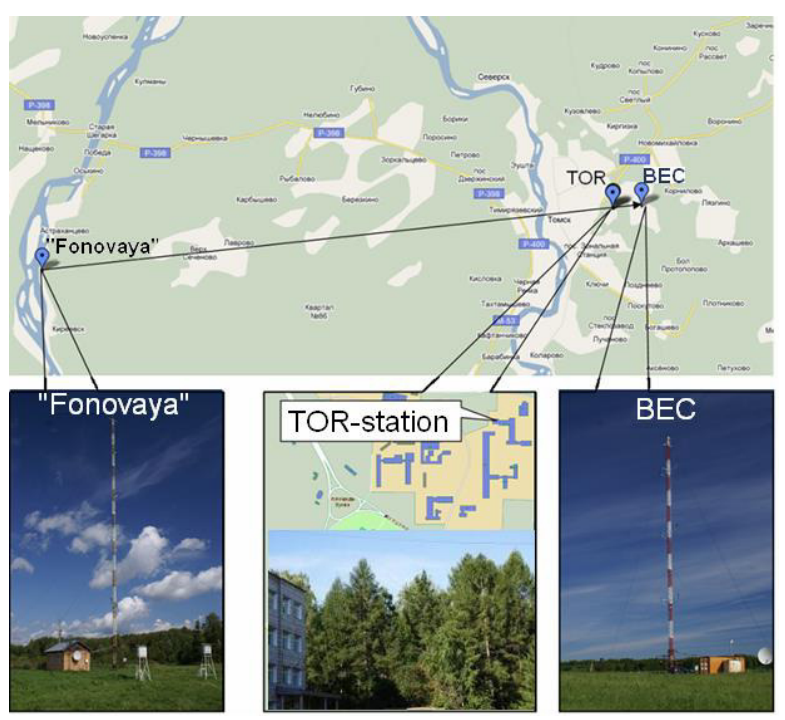

Fig. 1. Arrangement of stations for atmospheric monitoring: (left) Fonovaya Observatory, (center) TOR station, and (right) BEK.

The Fonovaya Observatory is located $60 \mathrm{~km}$ to the west of Tomsk, Siberian Lidar Station and the TOR station is situated at the northeastern end of the Tomsk Scientific Center (Akademgorodok), and BEC lies in suburbs $3 \mathrm{~km}$ to the east from Akademgorodok. This arrangement of the stations 
(nearly in line) in the case of the west-eastern transport of air mass allows us to estimate the anthropogenic contribution of the city of Tomsk to the formation of the field of atmospheric pollutants. The vertical distribution of the climatically significant components of the troposphere was studied with the Tu-134 Optik flying laboratory. The Tu-134 Optik flying laboratory carried out a sounding flight over the territory of Ob-Tom interfluve southwest of Tomsk (on Kozhevnikovo - Kurlek traverse) on April 9, 2013. Regular monitoring of the aerosol optical thickness (AOT) of the atmosphere was carried out at the two observation sites: in Tomsk (IAO SB RAS) and at the Fonovaya Observatory. At the stationary Aerosol Station of IAO SB RAS located at the southeastern end of Tomsk, characteristics of the surface aerosol were monitored every hour round-the-clock. The Complex Aerosol Experiment on 2013 included a cycle of simultaneous two-site measurements at the IAO Aerosol Station in Tomsk and at the mobile Aerosol Station based at the Fonovaya Observatory in the forest zone $70 \mathrm{~km}$ to the west from Tomsk. The mass concentrations of aerosol and black carbon were measured every hour round-the-clock at the two measurement sites. Aerosol fields of the vertical depth of the troposphere were sensed with the aid of the LOZA-S stationary multifrequency lidar. The sensing in 2013 was conducted continuously starting from 06:00 local time to 20:00. In 2013, the two-site radiative experiment was conducted in Tomsk and at the Fonovaya Observatory. This experiment invoked the data of MODIS multichannel spectroradiometer installed on Terra and Aqua platforms of the EOS satellite system.

\section{RESULTS OF COMPLEX AEROSOL EXPERIMENT}

A series of experiments on laser sensing of the troposphere was performed in period from April 2 to 11, 2013, and radiosondes were launched in some days. Figure 2 presents two examples of comparison of the aerosol spatial distribution and radiosonde data. On a color scale, the figures present the profiles of backscattering coefficient in units of scattering ratio, defined as the ratio of total to molecular scattering. The meteorological data were obtained at ultrasonic meteorological station, located near lidar at height of $3 \mathrm{~m}$ above the sea surface. Based on balloonsonde data, we presented the relative humidity $\mathrm{r}$, the wind direction $\mathrm{D}$, and the equivalent-potential temperature (EPT) in degrees Kelvin. As can be seen from Figure 2, the meteorological situation on April 3 was characterized by the absence of clouds and considerable surface heating at preserved negative air temperatures. The balloonsonde profiles for 08:00 LT show decrease in relative humidity and veering of wind above the boundary of the boundary layer.

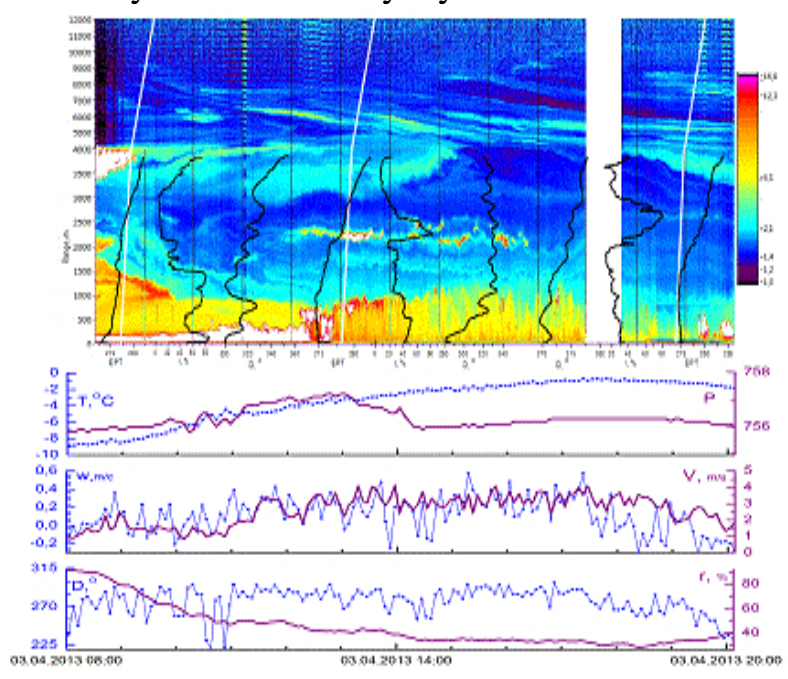

Figure 2 - The aerosol structure on April 3, 2013. White lines show the profiles of sonde ascents.

The vertical aerosol and black carbon profiles were measured onboard aircraft on pril 9 during flights in the region of Tomsk (Fig. 3).

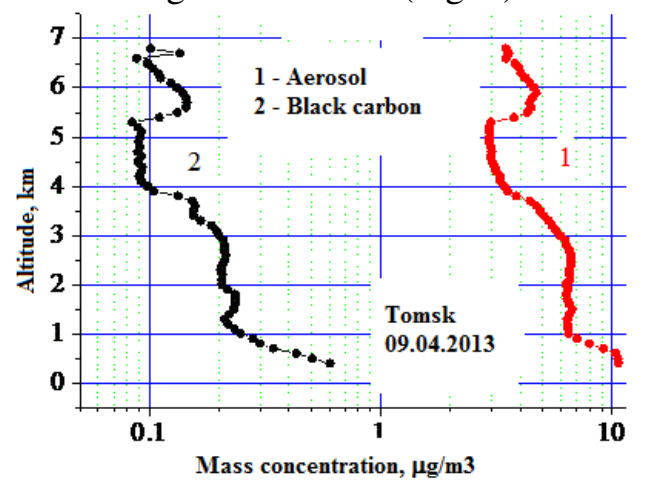

Figure 3 - Vertical aerosol and black carbon profiles according to data from flights of flying laboratory in the region of Tomsk on April 9.

Analysis of near-ground measurements at IAO aerosol station showed that aerosol characteristics exhibited qualitatively similar variations to those following from aircraft observations. The analysis was performed using diurnally average behaviors of dry bases of 
submicron aerosol and black carbon, normalized by their diurnally average values (Fig. 4). The diurnal behavior of condensation activity parameter $\gamma$ exhibits anticorrelation with behaviors of mass concentrations of submicron aerosol and black carbon (Fig. 5).

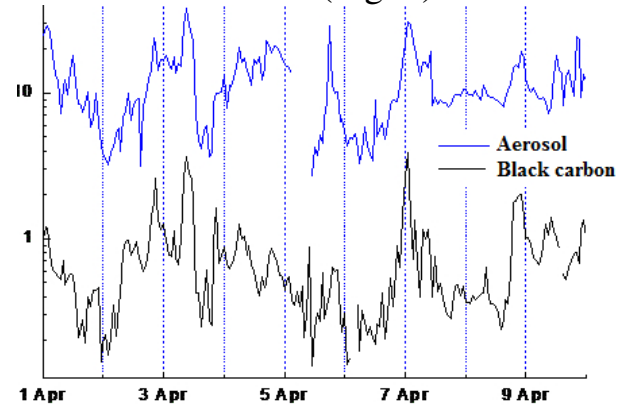

Figure 4 - Time behaviors of mass concentrations of dry base of submicron aerosol and black carbon on April 1-9, 2013.

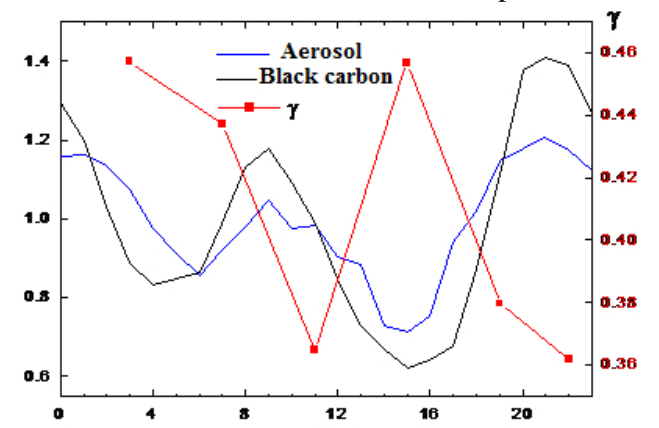

Figure 5 - Diurnally average normalized behaviors of mass concentrations of dry base of submicron aerosol and black carbon and diurnally average behavior of condensation activity parameter on April 1-9, 2013.

To date, the dataset of observations of size distribution of aerosol number concentration at TOR station and at Fonovaya observatory includes over 1900000 and 410000 measurements respectively. The decadally average values of the total number concentration varied in the ranges of $1.3 \cdot 10^{3}-1.2 \cdot 10^{4} \mathrm{~cm}^{-3}$ at the TOR station and $1.4 \cdot 10^{3}-5.8 \cdot 10^{3} \mathrm{~cm}^{-3}$ in the region of observatory. The average number concentration of aerosol particles over the entire period of observations was $4890 \mathrm{~cm}^{-3}\left( \pm 4905 \mathrm{~cm}^{-3}\right.$, median $\left.=3610 \mathrm{~cm}^{-3}\right)$ at TOR station and $3200 \mathrm{~cm}^{-3}\left( \pm 3244 \mathrm{~cm}^{-3}\right.$, median $=2561 \mathrm{~cm}^{-3}$ ) at Fonovaya station.

Comparison of numerical calculations and measurements of downward fluxes of the solar radiation at the Earth's surface. It is shown that relative differences between model and experimental values of the direct and total radiation, on the average, do not exceed $1 \%$ and $3 \%$ respectively when instrumental errors and determination uncertainties of atmospheric characteristics are taken into consideration. It is shown that under summer conditions the radiative cooling rates have local maximum at the height of approximately $3 \mathrm{~km}$, with the magnitude of the maximum being approximately $3.5 \mathrm{~K} /$ day.

\section{CONCLUSIONS}

The Complex Aerosol Experiment on measurement of various atmospheric parameters in the Siberian Region in 2013 has become a first step on the way of joining the efforts of different research groups aimed at obtaining the as complete as possible information about the state of the atmosphere under conditions of changing climate. Despite the short duration of the experiment, it has demonstrated the potential capabilities of available measuring facilities for longer measurements in the future. Nevertheless, the data obtained during the Complex Aerosol Experiment are of great value both for validation, correction, and calibration of satellite measurements and for validation and improvement of climatic models.

\section{ACKNOWLEDGEMENTS}

This work was supported in part by the Ministry of Science and Education of the Russian Federation (Agreements No. 14.613.21.0013 (RFMEFI61314X0013) and No. 14.604.21.0100 (RFMEFI60414X0100)), the Russian Science Foundation (Agreement no. 14-27-00022), the Russian Foundation for Basic Research (Grant No. 13-05-98074 - r_sibir-a), The President of the Russian Federation (Grant NS-4714.2014.5).

\section{REFERENCES}

[1] Arshinov, M.Yu., Belan, B.D., Davydov, D.K., Ivlev, G.A., Kozlov, A.V., Pestunov, D.A., Pokrovskii, E.V., Tolmachev, G.N., Fofonov, A.V., 2007. -Sites for monitoring of greenhouse gases and gases oxidizing the atmosphere. Atmospheric and oceanic optics, 20(1), 45-53.

[2] Anokhin, G.G., Antokhin, P.N., Arshinov, M.Yu., Barsuk, V.E., Belan, B.D., Belan, S.B., Davydov, D.K., Ivlev, G.A., Kozlov, A.V., Kozlov, V.S., Morozov, M.V., Panchenko, M.V., Penner, I.E., Pestunov, D.A., Sikov, G.P., Simonenkov, D.V., Sinitsyn, D.S., Tolmachev, G.N., Filipov, D.V., Fofonov, A.V., Chernov, D.G., Shamanaev, V.S., Shmargunov, V.P., 2011, - OPTIK Tu-134 aircraft laboratory. Atmospheric and oceanic optics. 24(9), 805-816. 